\title{
Effect of Aerobic Exercise on Bone Mineral Density in Lean Postmenopausal Women
}

\author{
MOHAMED A. AWAD, Ph.D.*; ENGY M. EL-NAHAS, Ph.D.*; MOHAMMED R. SOLIMAN, M.D.** and \\ MARWA A. BIOMY, M.Sc.***
}

The Department of Physical Therapy for Obstetrics \& Gynecology, Faculty of Physical Therapy, Cairo University*,

The Department of Obstetrics \& Gynecology, Faculty of Medicine, Ain Shams University** and

The Department of Physical Therapy, Faculty of Physical Therapy, Cairo University***, Egypt

\begin{abstract}
Background: Osteoporosis is considered as the most common bone disease in humans, and it represents a major public health problem as outlined in Bone Health and Osteoporosis.

Aim of Study: This study was carried out to determine the effect of aerobic exercises on bone mineral density in lean postmenopausal women.

Participants: Forty osteoporotic lean postmenopausal women participated in this study. Their ages were ranged from 49-69 years. Their Body Mass Index (BMI) was less than $25 \mathrm{~kg} / \mathrm{m} 2$. Their T-Score was less than -2.5 . The study was conducted from January to July 2017.
\end{abstract}

Design: They were selected randomly from outpatient clinic of Physiotherapy Department.

Location: This study conducted at they were selected from Physiotherapy Department in Abu-Elmatameer General Hospital in Abu-Elmatameer City, Behera Governate.

Material and Methods: They were divided randomly into two groups equal in number (A and B). Group A (study group) performed aerobic exercise in the form of walking on treadmill, for thirty minutes, three times per week for twelve weeks, starting with warming up exercises and ended by cooling down exercises in addition to their usual daily calcium intake (cal preg tablets $1200 \mathrm{mg} /$ day). Group B (control group) took only their usual daily calcium intake (cal preg tablets 1200 $\mathrm{mg} /$ day). Evaluation all women in both groups (A and B) were assessed pre and post treatment program.

Outcome Measure: Measuring Bone Mineral Density (BMD) of lumbar regain, left femur and forearm by using DEXA.

Results: There was highly statistical significant increase in the mean values of BMD and T-score of lumbar spine, left femur and forearm post treatment in both groups A and B There was no statistical significant difference between both groups (A \& B) pre treatment in the mean values of BMD \&

Correspondence to: Dr. Mohamed A. Awad, The Department of Physical Therapy for Obstetrics and Gynecology, Faculty of Physical Therapy, Cairo University, Egypt
T-score of lumbar spine, left femur and forearm where the $p$ value was $(>0.05)$. While, post-treatment there was a statistical significant difference between both groups (A \& B) in the mean values of BMD \& T-score of lumbar spine, left femur and for arm where, the $p$-value was $(<0.05)$ in favor of group A (more increase)

Conclusion: It can be concluded that aerobic exercise has been shown to be effective in improving bone mineral density in lean post-menopausal women.

Key Words: Aerobic exercise - Bone mineral density - Post menopausal.

\section{Introduction}

MENOPAUSE is the permanent end of menstruation and fertility, defined as occurring 12 months after the last menstrual period. It is a natural biological process. Although it ends fertility, one may remain healthy, vital and sexual. Even so, the physical and emotional symptoms of menopause may disrupt sleeping pattern, cause hot flashes, trigger anxiety or feelings of sadness and loss. Many effective treatments are available, from lifestyle adjustments to hormone therapy [1]

Post menopause can come across as an enigmatic time of life, the first time in decades that a woman does not have the capacity to reproduce. After having gone through pre menopause, peri menopause, and menopause itself, women will enter the last stage along the reproductive route, during postmenopausal period, hormonal fluctuations might still occur within women's bodies, sometimes prolonging symptoms. Besides hormonal causes, experts have also identified external causes [2]

Osteoporosis is a degenerative bone disorder, characterized by thinning and weakening of the bone and a general decrease in bone mass and 
density. Menopause negatively affects bone growth. Normally, bones go through a process whereby old bone is replaced with new bone cells, but the body's ability to handle this process changes with age. By around age 35 there is less bone growth. Estrogen is involved in the process of calcium absorption into the bones; thus, due to the drop in estrogen levels, women will experience an accelerated reduction in bone density. Reduced bone density means that bones are much more susceptible to fractures [3].

Osteoporosis is characterized by low bone mass and an increased risk of fracture [4]. Fractures most commonly associated with osteoporosis are those of the hip, the vertebrae, and the wrist, and these are responsible for morbidity and excess mortality. Many clinical guidelines recommend risk factor assessment and measurement of Bone Mineral Density (BMD) through dual energy X-ray absorptiometry (DEXA) to identify individuals at high risk of fracture [5]. Risk factors have been extensively characterized in women over the age of 65 years and are used in practice, often in combination, to predict fractures [6].

Bone Mineral Density (BMD), is a medical term normally referring to the amount of mineral matter per square centimeter of bones. It is used in clinical medicine as an indirect indicator of osteoporosis and fracture risk [7].

Bone mineral density positively correlates with Body Mass Index (BMI) in postmenopausal, and to a lesser degree in premenopausal women [8] .

There is general agreement on the fact that low bone mineral density is strongly associated with fracture risk in osteoporotic postmenopausal women [9]. It follows that knowledge of the factors modulating the behavior of bone mass is crucial for preventing and treating osteoporotic disease. Among these factors, body weight has been shown to be of primary importance in postmenopausal women [10]

Prospective studies indicate that early postmenopausal women with lower BMI lose more bone as compared with those with higher BMI, as thinness is related to both osteoporosis and increased fracture risk, low BMI was included in the risk assessment tools for evaluation of osteoporosis and osteoporotic fracture risk [11]. Estrogen deficiency is the primary factor interfering with normal bone remodeling and leading to osteoporosis in postmenopausal women. Though estrogen insufficiency increases both bone formation and resorp- tion. Bone resorption is the predominant effect leading to low bone mass and quality [12].

Increased secretion of osteopclastognic cytokines such as Interlukin- 1 (IL-1). Inteleukin-6 (IL-6) and Tumor Necrosis Factor Alpha (TNFct), imbalance of receptor activator of nuclear factor ligand/osteoprotegerin (RANKL/OPG) gene expression, and inhibition of osteoclast apoptosis are some suggested mechanisms. Decrease in progesterone androstenedione and androsternedione/ SHBG ratio 38 and inhibin $A$ and $B$ are possible hormonal contributors to postmenopausal osteoporosis [13]

Exercise plays an essential role in the treatment of osteoporosis. Anaerobic and aerobic training have been shown to be effective methods of exercise for improving BMD and reducing bone loss. Wolff' s law states that, human and animal bone adapts to new or unusual mechanical stress by altering the bone architecture. Bone tissue will adjust by increasing osteoblast formation in the areas affected by mechanical stress. Conversely, with a lack of mechanical stress, the bone will progressively weaken because of resorption exceeding bone growth. For bone formation to occur, a Minimal Essential Strain (MES) is required. MES is the minimal threshold required for human bone formation. It is estimated that the MES for the human bone is approximately $1 / 10$ of what is required for a fracture. Exercise can provide the necessary essential strain to maintain and promote bone growth. Exercise has been found to be an effective treatment for osteoporosis in postmenopausal women. Wolff et al., conducted a systematic review of published articles that examined the effect of exercise on BMD. The study concluded that exercise training prevented or reversed bone loss by close to $1 \%$ per year in both premenopausal and postmenopausal women [14].

Aerobic exercises, especially walking, appear to be the most common and preferred exercise in older adults, but they have limited potential in improving bone mass as they provide minimal loading on the skeleton. A review of 12 trials of aerobic training concluded that aerobic exercises retard bone loss without significant improvements of BMD [15].

Aerobic training is a type of endurance training that involves cyclic exercises through an extended period of time with no additional loading or with a very little external loading. Its main goal is to improve the capacity and performance of respiratory and cardiovascular system. One of the most 
essential adaptations to aerobic endurance training and one of the important indicators of healthy cardiovascular system is maximal oxygen consumption $\left(\mathrm{VO} 2_{\max }\right)$. That is why aerobic training is probably the most important type of training for elderly population. Aerobic training lead to maintaining and/or reducing the loss of bone mass, we should take this type of training into consideration when programing interventions focused on maintaining bone quality in elderly people [14]

\section{Subjects, Material and Methods}

\section{I- Subjects:}

Forty osteoporotic lean postmenopausal women participated in this study. They were selected from Physiotherapy Department in Abu El-Matameer General Hospital in Abu El-Matameer City, Behera Governate. Their ages were ranged from 49-69 years. Their Body Mass Index (BMI) was less than $25 \mathrm{~kg} / \mathrm{m} 2$. Their T-Score was less than -2.5 . Women with diabetes mellitus, hypertension and cardiac diseases, psychological problems or cognitive problems are excluded from the study. Duration of this study was 6 months from January 2017 to July 2017. They were divided randomly into two groups equal in number (A and B). Group A (study group) performed aerobic exercise in the form of walking on treadmill, for thirty minutes, three times per week for twelve weeks, starting with warming up exercises and ended by cooling down exercises in addition to their usual daily calcium intake (cal preg tablets $1200 \mathrm{mg} /$ day). Group B (control group) took only their usual daily calcium intake (cal preg tablets $1200 \mathrm{mg} /$ day).

\section{II- Material:}

1- Informed consent form.

2- Weight-height scale. It was used to measure weight and height to calculate Body Mass Index (BMI) for each woman both groups (A \& B).

3- Dual Energy X-ray Absorptiometry (DEXA). It was used to measure the bone mineral density of the lumbar spine, femur and forearm for each participant in both groups (A \& B) before and after the study.

4- Treadmill machine. Training equipment (motorized treadmill) $(170 \mathrm{CE}, 220 \mathrm{~V}, 50 \mathrm{~Hz}, 10 \mathrm{~A}$ and 2.2 kilowatts) was used as a method of aerobic exercise for group (A).

\section{III- Producers:}

\section{A- Evaluation procedures:}

All women were given a full explanation of the protocol of the study and informed consent form was signed from each woman before participating in this study. All data was recorded in a recording data sheet.

1-Assessment of BMI: Weight and height were measured while the woman wearing a thin layer of clothes to calculate the BMI for each woman in both groups according to the following equation:

$$
\operatorname{BMI}\left(\mathrm{kg} / \mathrm{m}^{2}\right)=\frac{\text { Weight }(\mathrm{kg})}{\text { Height2 }\left(\mathrm{m}^{2}\right)}
$$

2- Dual Energy X-ray Absorptiometry (DEXA):

- On the day of the exam, patient was instructed to eat normally and don't take calcium supplements for at least 24 hours before exam.

- Patient was instructed to wear loose comfortable clothing, avoiding garments that have zippers, belts or buttons made of metal. Objects such as keys or wallets that would be in the area being scanned should be removed.

- Patient was asked to remove some of her clothes and to wear a gown during the exam.

- Patient was asked to remove jewelry, removable dental appliances, eye glasses and any metal objects or clothing that might interfere with the $\mathrm{X}$-ray images.

- To assess the lumbar spine, the patient's legs were supported on a padded box to flatten the pelvis and lower (lumbar) spine, to assess the hip, the patient's foot was placed in a brace that rotated the hip inward Fig. (1).

- In both cases, the detector was slowly passed over the area, generating images on a computer monitor.

- Patient was instructed to be hold very still and asked to keep from breathing for a few seconds while the X-ray picture is taken to reduce the possibility of a blurred image. The technologist would walk behind a wall or into the next room to activate the X-ray machine.

- The peripheral test was simpler; the forearm was placed in a small device that obtains a bone density reading within a few minutes Fig. (2).

\section{A- Treatment procedures:}

Group A:

Each patient in this group performed aerobic exercise in the form of walking on treadmill for 30 minutes classified as the following: 5 minutes warming up by walking on treadmill with low speed then 20 minutes walking at moderate intensity (70\% of maximum heart rate) and 5 minutes cooling 
down by walking on treadmill with low speed as warming up.

The treatment session was repeated 3 times/ week for 3 months Fig. (3). In addition to their usual daily calcium intake (cal preg tablets 1200 $\mathrm{mg} /$ day).

\section{Group B:}

Each patient in this group took their usual calcium intake (cal preg tablets $1200 \mathrm{mg} /$ day).

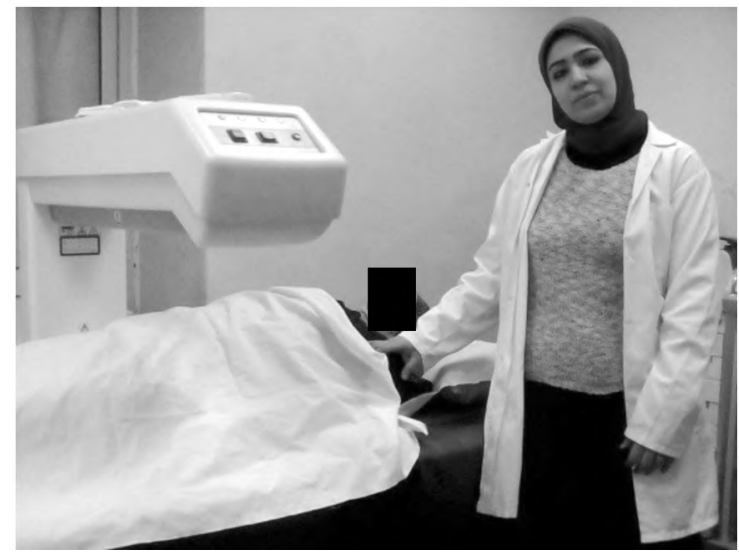

Fig. (1): Application of DEXA on lumbar spine and left femur.

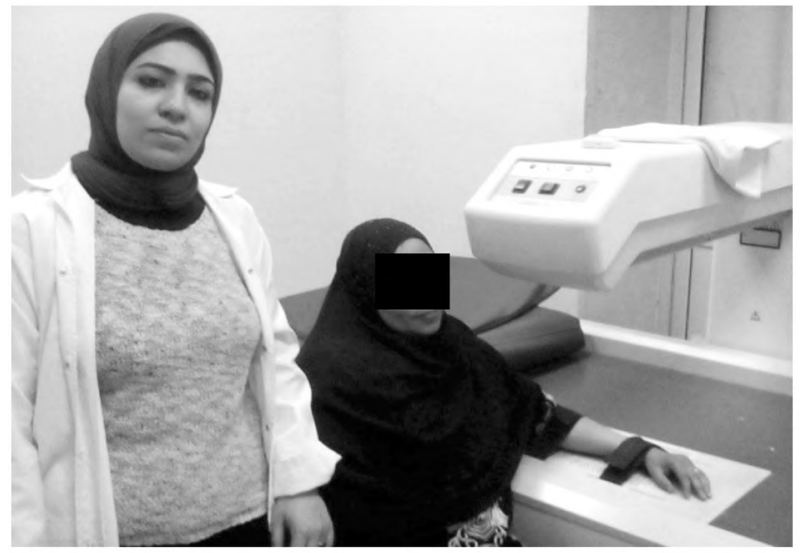

Fig. (2): Application of DEXA on left forearm.

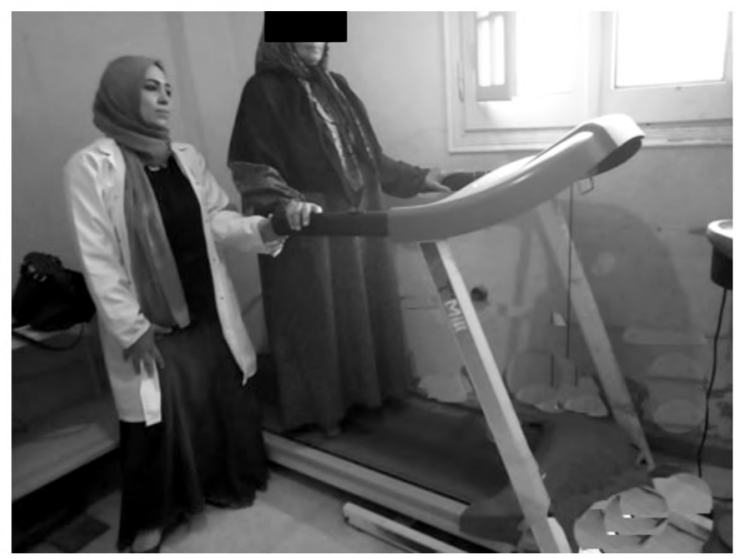

Fig. (3): Patient while performing aerobic exercise.

\section{Statistical analysis:}

Results are expressed as mean \pm standard deviation. Test of normality, Kolmogorov-Smirnov test, was used to measure the distribution of data measured pre-treatment. Accordingly, comparison between variables in the two groups was performed using unpaired $t$-test. Comparison between variables measured pre-and post-treatment in the same group was performed using paired $t$-test.

Difference was calculated as follows: Pretreatment-post-treatment. Percent of change was calculated as follows: [(Pre-treatment-post-treatment)/pre-treatment] X 100. Statistical Package for Social Sciences (SPSS) computer program (Version 19 windows) was used for data analysis. $p$-value $\leq 0.05$ was considered significant.

\section{Results}

\section{I- Physical characteristics of patients:}

There was no statistical significant differences between both groups (A and B) in their ages, weight, height and body mass index, where their $t$ and $p$-values were $(-1.585,0.121),(-1.652$, $0.107),(-0.764,0.450)$ and $(-1.919,0.062)$, respectively.

Table (1): Physical characteristics of patients in both groups (A \& B)

\begin{tabular}{llllc}
\hline & $\begin{array}{c}\text { Group (A) } \\
(\mathrm{n}=20)\end{array}$ & $\begin{array}{c}\text { Group (B) } \\
(\mathrm{n}=20)\end{array}$ & $\begin{array}{c}t \text { - } \\
\text { value }\end{array}$ & $\begin{array}{c}p- \\
\text { value }\end{array}$ \\
\hline Age (yrs.) & $55.61 \pm 5.98$ & $58.54 \pm 5.68$ & -1.585 & $0.121(\mathrm{NS})$ \\
Weight (Kg.) & $57.50 \pm 5.94$ & $60.80 \pm 6.67$ & -1.652 & $0.107(\mathrm{NS})$ \\
Height $(\mathrm{cm} .2)$ & $160.85 \pm 6.63$ & $162.50 \pm 7.03$ & -0.764 & $0.450(\mathrm{NS})$ \\
BMI (kg/m $)$ & $22.19 \pm 1.35$ & $22.96 \pm 1.19$ & -1.919 & $0.062(\mathrm{NS})$ \\
\hline
\end{tabular}

Data are expressed as mean $\pm \mathrm{SD}$.

NS: $p>0.05$ : Not Significant.

\section{II- Bone Mineral Density (BMD):}

\section{A- BMD in lumbar spine:}

Within groups:

There was highly statistical significant increase in BMD of lumbar spine at post-treatment in both groups $\mathrm{A}$ and $\mathrm{B}$ where $p$-value was 0.001 in $t$-value was ( -9.856 and -9.200 respectively). The percentage of increase in BMD of lumbar spine in both groups (A \& B) was $1.84 \%$ and $0.74 \%$, respectively.

\section{Between groups:}

At pre-treatment there was no statistical significant difference between mean value of BMD of lumbar spine of group (A) and its corresponding value in group (B) with $t$-value $=0.475$ and $p$-value $=$ 0.637 . While at post-treatment, there was statistical significant difference in mean value of BMD of 
group (A) when compared with its corresponding value in group (B) with $t$-value $=2.929$ and $p$-value $=0.006$.

Table (2): Mean values of BMD in lumbar spine measured pre-and post-treatment in both groups (A \& B).

\begin{tabular}{lll}
\hline $\begin{array}{l}\text { BMD of lumbar spine } \\
\left(\mathrm{gm} / \mathrm{cm}^{2}\right)\end{array}$ & $\begin{array}{c}\text { Group (A) } \\
(\mathrm{n}=20)\end{array}$ & $\begin{array}{c}\text { Group (B) } \\
(\mathrm{n}=20)\end{array}$ \\
\hline Pre-treatment & $0.814 \pm 0.013$ & $0.812 \pm 0.012$ \\
Post-treatment & $0.829 \pm 0.011$ & $0.818 \pm 0.012$ \\
Mean difference & -0.015 & -0.006 \\
Percentage of change & $1.84 \% \uparrow \uparrow$ & $0.74 \% \uparrow \uparrow$ \\
$t$-value & -9.856 & -9.200 \\
$p$-value & 0.001 (HS) & 0.001 (HS) \\
\hline
\end{tabular}

Data are expressed as mean $\pm \mathrm{SD}$.

HS: $p>0.05$ : High Significant.

Table (3): Comparison between mean values of BMD in lumbar spine in both groups (A \& B) measured pre-and post-treatment.

\begin{tabular}{lcccc}
\hline $\begin{array}{l}\text { BMD of } \\
\text { lumbar spine }\end{array}$ & $\begin{array}{c}\text { Group (A) } \\
(\mathrm{n}=20)\end{array}$ & $\begin{array}{c}\text { Group (B) } \\
(\mathrm{n}=20)\end{array}$ & $\begin{array}{c}t- \\
\text { value }\end{array}$ & $\begin{array}{c}p \text { - } \\
\text { value }\end{array}$ \\
\hline Pre-treatment & $0.814 \pm 0.013$ & $0.812 \pm 0.012$ & 0.475 & 0.637 (NS) \\
Post-treatment & $0.829 \pm 0.011$ & $0.818 \pm 0.012$ & 2.929 & 0.006 (S) \\
\hline
\end{tabular}

Data are expressed as mean $\pm \mathrm{SD}$

NS: $p>0.05$ : Not Significant.

S: $p<0.05$ : Significant.

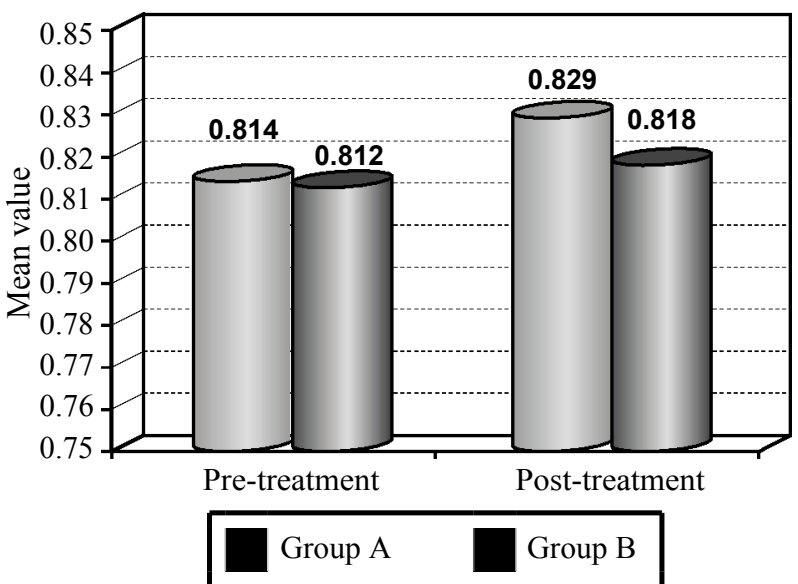

Fig. (4): Comparison between mean values of BMD in lumbar spine in both groups (A \& B) measured pre-and posttreatment.

\section{B- BMD in left femur:}

\section{Within groups.}

There was highly statistical significant increase in BMD of left femur in post-treatment in both groups $\mathrm{A}$ and $\mathrm{B}$ where $p$-value was 0.001 and $t$ value was $(-5.316$ and -16.938 respectively). The percentage of increase in $\mathrm{BMD}$ in both groups (A \& B) was $1.31 \%$ and $0.60 \%$, respectively.

\section{b- Between groups:}

At pre-treatment there was no statistical significant difference between mean value of BMD of left femur of group (A) and its corresponding value in group (B) with $t$-value $=1.052$ and $p$-value $=0.300$. While at post-treatment, there was statistical significant difference in mean value of BMD of group (A) when compared with its corresponding value in group (B) with $t$-value $=2.357$ and $p$-value $=0.024$.

Table (4): Mean values of BMD in left femur measured preand post-treatment in both groups (A \& B)

\begin{tabular}{lcl}
\hline BMD of left femur & Group (A) $(\mathrm{n}=20)$ & Group (B) $(\mathrm{n}=20)$ \\
\hline Pre-treatment & $0.843 \pm 0.009$ & $0.840 \pm 0.010$ \\
Post-treatment & $0.854 \pm 0.015$ & $0.845 \pm 0.010$ \\
Mean difference & -0.011 & -0.005 \\
Percentage of change & $1.31 \% \uparrow \uparrow$ & $0.60 \% \uparrow \uparrow$ \\
$t$-value & -5.316 & -16.938 \\
$p$-value & 0.001 (HS) & 0.001 (HS) \\
\hline
\end{tabular}

Data are expressed as mean \pm SD.

HS: $p>0.05$ : High Significant

Table (5): Comparison between mean values of BMD in of left femur in both groups (A \& B) measured preand post-treatment.

\begin{tabular}{lcccl}
\hline $\begin{array}{l}\text { BMD in of } \\
\text { left femur }\end{array}$ & $\begin{array}{c}\text { Group (A) } \\
(\mathrm{n}=20)\end{array}$ & $\begin{array}{c}\text { Group (B) } \\
(\mathrm{n}=20)\end{array}$ & $\begin{array}{c}t- \\
\text { value }\end{array}$ & $\begin{array}{c}p- \\
\text { value }\end{array}$ \\
\hline Pre-treatment & $0.843 \pm 0.009$ & $0.840 \pm 0.010$ & 1.052 & 0.300 (NS) \\
Post-treatment & $0.854 \pm 0.015$ & $0.845 \pm 0.010$ & 2.357 & $0.024(\mathrm{~S})$
\end{tabular}

Data are expressed as mean $\pm \mathrm{SD}$.

NS: $p>0.05$ : Not Significant: $p<0.05$ : Significant.

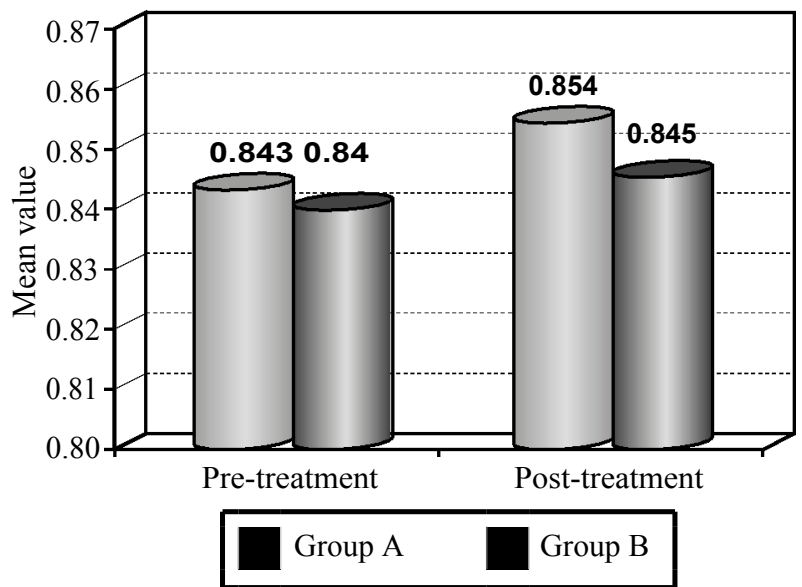

Fig. (5): Comparison between mean values of BMD in left femur in both groups (A \& B) measured pre-and post-treatment.

\section{B- BMD in left forearm:}

\section{Within groups:}

There was highly statistical significant increase in $\mathrm{BMD}$ in post-treatment in both groups $\mathrm{A}$ and $\mathrm{B}$ where $p$-value was 0.001 in BMD and $t$-value was $(-17.601$ and -6.364 respectively). The percentage increase in MBD of left forearms in both groups (A \& B) was $1.31 \%$ and $0.48 \%$, respectively.

\section{b- Between groups:}

At pre-treatment there was no statistical significant difference between mean value of BMD of 
left forearm of group (A) and its corresponding value in group (B) with $t$-value $=1.590$ and $p$. value $=0.120$. While at post-treatment, there was highly statistical significant difference in mean value of BMD of left forearm of group (A) when compared with its corresponding value in group (B) with $t$-value $=3.063$ and $p$-value $=0.004$.

Table (6): Mean values of BMD in left forearm measured preand post-treatment in both groups (A \& B).

\begin{tabular}{lcc}
\hline BMD of left forearm & Group (A) $(\mathrm{n}=20)$ & Group (B) $(\mathrm{n}=20)$ \\
\hline Pre-treatment & $0.646 \pm 0.004$ & $0.644 \pm 0.005$ \\
Post-treatment & $0.654 \pm 0.005$ & $0.649 \pm 0.004$ \\
Mean difference & -0.008 & -0.005 \\
Percentage of change & $1.24 \% \uparrow \uparrow$ & $0.78 \% \uparrow \uparrow$ \\
$t$-value & -17.601 & -6.364 \\
$p$-value & 0.001 (HS) & $0.001(\mathrm{HS})$ \\
\hline
\end{tabular}

Data are expressed as mean $\pm \mathrm{SD}$.

HS: $p<0.05$ : High Significant.

Table (7): Comparison between mean values of BMD in left forearm in both groups (A \& B) measured pre-and post-treatment.

\begin{tabular}{lcccc}
\hline $\begin{array}{l}\text { BMD of } \\
\text { left forearm }\end{array}$ & $\begin{array}{c}\text { Group (A) } \\
(\mathrm{n}=20)\end{array}$ & $\begin{array}{c}\text { Group (B) } \\
(\mathrm{n}=20)\end{array}$ & $\begin{array}{c}t \text { - } \\
\text { value }\end{array}$ & $\begin{array}{c}p \text { - } \\
\text { value }\end{array}$ \\
\hline Pre-treatment & $0.646 \pm 0.004$ & $0.644 \pm 0.005$ & 1.590 & $0.120(\mathrm{NS})$ \\
Post-treatment & $0.654 \pm 0.005$ & $0.649 \pm 0.004$ & 3.063 & $0.004(\mathrm{~S})$ \\
\hline
\end{tabular}

Data are expressed as mean $\pm \mathrm{SD}$.

NS: $p>0.05$ : Not Significant: $p<0.05$ : Significant.

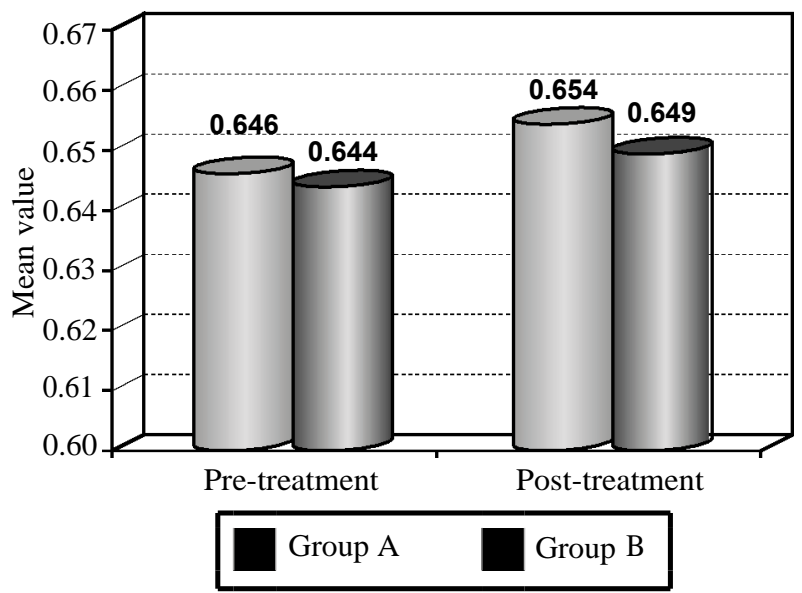

Fig. (6): Comparison between mean values of BMD in left forearm in both groups (A \& B) measured pre-and post-treatment.

III- $T$ score:

\section{A- T score in lumbar spine:}

Within groups:

There was highly statistical significant increase in $\mathrm{T}$ score of lumbar spine at post-treatment in both groups $\mathrm{A}$ and $\mathrm{B}$ where $p$-value was 0.001 and $t$-value was ( -9.452 and -6.000 respectively). The percentage increase in $\mathrm{T}$ score of lumbar spine in both groups (A \& B) was $9.42 \%$ and $3.93 \%$, respectively.
Table (8): Mean values of T score in lumbar spine measured pre-and post-treatment in both groups (A \& B).

\begin{tabular}{lll}
\hline T-Score of lumbar spine & Group (A) $(\mathrm{n}=25)$ & Group $(\mathrm{B})(\mathrm{n}=25)$ \\
\hline Pre-treatment & $-3.025 \pm 0.174$ & $-3.055 \pm 0.209$ \\
Post-treatment & $-2.740 \pm 0.164$ & $-2.935 \pm 0.184$ \\
Mean difference & 0.285 & 0.120 \\
Percentage of change & $9.42 \% \uparrow \uparrow$ & $3.93 \% \uparrow \uparrow$ \\
$t$-value & -9.452 & -6.000 \\
$p$-value & $0.001(\mathrm{HS})$ & 0.001 (HS) \\
\hline
\end{tabular}

Data are expressed as mean \pm SD. HS: $p<0.05$ : High Significant.

\section{b- Between groups:}

At pre-treatment there was no statistical significant difference between mean value of $\mathrm{T}$ score of lumbar spine of group (A) and its corresponding value in group (B) with $t$-value $=0.493$ and $p$-value $=0.625$. While at post-treatment, there was statistical significant difference in mean value of $\mathrm{T}$ score of group (A) $(-2.740 \pm 0.164)$ when compared with its corresponding value in group (B) $(-2.935 \pm$ 0 . 184) with $t$-value $=3.539$ and $p$-value $=0.001$.

Table (9): Comparison between median values of $\mathrm{T}$ score in lumbar spine in both groups (A \& B) measured pre-and post-treatment.

\begin{tabular}{lcccl}
\hline $\begin{array}{l}\text { T-score of } \\
\text { lumbar spine }\end{array}$ & $\begin{array}{c}\text { Group (A) } \\
(\mathrm{n}=20)\end{array}$ & $\begin{array}{c}\text { Group (B) } \\
(\mathrm{n}=20)\end{array}$ & $\begin{array}{c}t \text { - } \\
\text { value }\end{array}$ & $\begin{array}{c}p \text { - } \\
\text { value }\end{array}$ \\
\hline Pre-treatment & $-3.025 \pm 0.174$ & $-3.055 \pm 0.209$ & 0.493 & 0.625 (NS) \\
Post-treatment & $-2.740 \pm 0.164$ & $-2.935 \pm 0.184$ & 3.539 & $0.001(\mathrm{~S})$ \\
\hline
\end{tabular}

Data are expressed as mean \pm SD.

NS: $p>0.05$ : Not Significant.

S: $p<0.05$ : Significant.

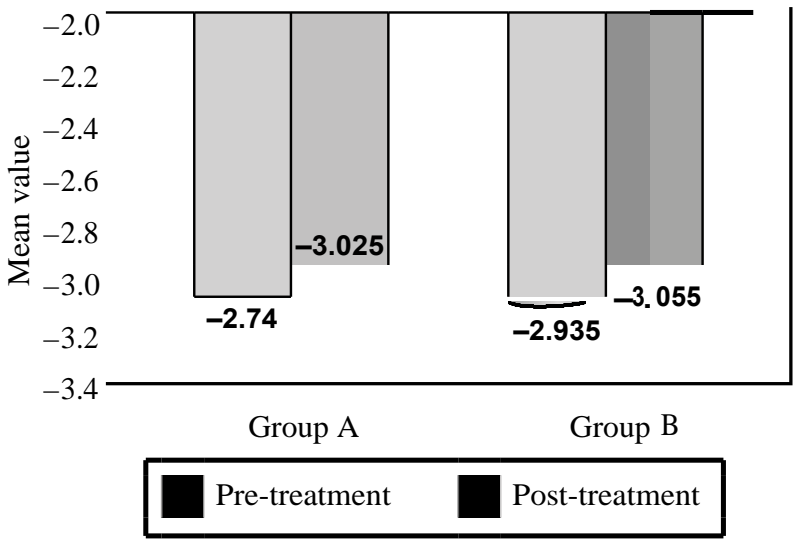

Fig. (7): Comparison between mean values of $\mathrm{T}$ score in lumbar spine in both groups (A \& B) measured preand post-treatment.

\section{B- $T$ score in left femur:}

Within groups:

There was highly statistical significant increase in $\mathrm{T}$ score of left femur at post-treatment in both groups $\mathrm{A}$ and $\mathrm{B}$ where $p$-value was 0.001 and $t$ value was ( -9.703 and -7.667 respectively). The percentage of increase in $\mathrm{T}$ score of left femur in both groups (A \& B) was $17.21 \%$ and $8.88 \%$, respectively. 
Table (10): Mean values of T score in left femur measured pre-and post-treatment in both groups (A \& B).

\begin{tabular}{lll}
\hline T-Score left femur & Group (A) $(\mathrm{n}=25)$ & Group (B) $(\mathrm{n}=25)$ \\
\hline Pre-treatment & $-1.220 \pm 0.177$ & $-1.295 \pm 0.252$ \\
Post-treatment & $-1.010 \pm 0.162$ & $-1.180 \pm 0.222$ \\
Mean difference & 0.210 & 0.115 \\
Percentage of change & $17.21 \% \uparrow \uparrow$ & $8.88 \% \uparrow \uparrow$ \\
$t$-value & -9.703 & -7.667 \\
$p$-value & 0.001 (HS) & 0.001 (HS) \\
\hline
\end{tabular}

Data are expressed as mean $\pm \mathrm{SD}$

HS: $p<0.05$ : High Significant

\section{b- Between groups:}

At pre-treatment there was no statistical significant difference between mean value of $\mathrm{T}$ score of left femur of group (A) and its corresponding value in group (B) with $t$-value $=1.089$ and $p$-value $=$ 0.284 . While at post-treatment, there was statistical significant difference in mean value of $\mathrm{T}$ score of group (A) $(-1.010 \pm 0.162)$ when compared with its corresponding value in group (B) $(-1.180 \pm 0.222)$ with $t$-value $=2.771$ and $p$-value $=0.009$.

Table (11): Comparison between median values of $T$ score of left femur in both groups (A \& B) measured preand post-treatment.

\begin{tabular}{lcccl}
\hline $\begin{array}{l}\text { T-score of } \\
\text { left femur }\end{array}$ & $\begin{array}{c}\text { Group (A) } \\
(\mathrm{n}=20)\end{array}$ & $\begin{array}{c}\text { Group (B) } \\
(\mathrm{n}=20)\end{array}$ & $\begin{array}{c}t \text { - } \\
\text { value }\end{array}$ & $\begin{array}{c}p \text { - } \\
\text { value }\end{array}$ \\
\hline Pre-treatment & $-1.220 \pm 0.177$ & $-1.295 \pm 0.252$ & 1.089 & 0.284 (NS) \\
Post-treatment & $-1.010 \pm 0.162$ & $-1.180 \pm 0.222$ & 2.771 & 0.009 (S)
\end{tabular}

Data are expressed as mean \pm SD.

NS: $p>0.05$ : Not Significant.

\section{S: $p<0.05$ : Significant}

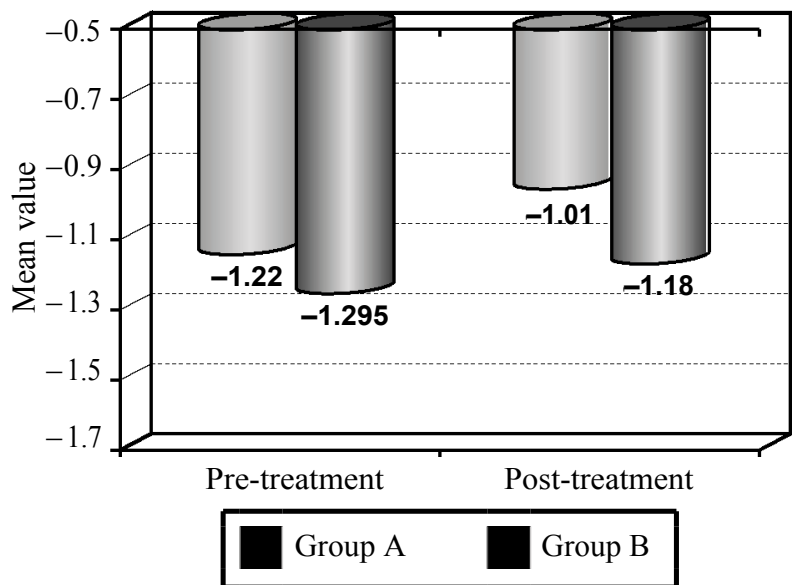

Fig. (8): Comparison between mean values of $\mathrm{T}$ score in left femur in both groups (A \& B) measured pre-and post-treatment.

\section{C- $T$ score of left forearm:}

\section{Within groups:}

There was highly statistical significant increase in $\mathrm{T}$ score of left forearm at post-treatment in both groups $\mathrm{A}$ and $\mathrm{B}$ where $p$-value was 0.001 and $t$ value was $(-11.961$ and -6.474 respectively). The percentage of increase in $\mathrm{T}$ scores of left forearm in both groups A \& B was $17.11 \%$ and $8.76 \%$, respectively.

Table (12): Mean values of T score of left forearm measured pre-and post-treatment in both groups (A \& B).

\begin{tabular}{lll}
\hline T-score of left forearm & Group (A) $(\mathrm{n}=25)$ & Group (B) $(\mathrm{n}=25)$ \\
\hline Pre-treatment & $-0.935 \pm 0.104$ & $-0.970 \pm 0.098$ \\
Post-treatment & $-0.775 \pm 0.097$ & $-0.885 \pm 0.088$ \\
Mean difference & 0.160 & 0.085 \\
Percentage of change & $17.11 \% \uparrow \uparrow$ & $8.76 \% \uparrow \uparrow$ \\
$t$-value & -11.961 & -6.474 \\
$p$-value & 0.001 (HS) & 0.001 (HS)
\end{tabular}

Data are expressed as mean \pm SD.

HS: $p<0.05$ : High Significant.

\section{b- Between group comparisons:}

At pre-treatment there was no statistical significant difference between mean value of $\mathrm{T}$ score of left forearm of group (A) and its corresponding value in group (B) with $t$-value $=1.096$ and $p$-value $=0.280$. While at post-treatment, there was statistical significant difference in mean value of $\mathrm{T}$ score of left forearm of group (A) when compared with its corresponding value in group (B) with $t$-value $=$ 3.773 and $p$-value $=0.001$.

Table (13): Comparison between median values of $\mathrm{T}$ score in fore arm in both groups (A \& B) measured preand post-treatment.

\begin{tabular}{lcccc}
\hline $\begin{array}{l}\text { T-score of } \\
\text { left forearm }\end{array}$ & $\begin{array}{c}\text { Group (A) } \\
(\mathrm{n}=20)\end{array}$ & $\begin{array}{c}\text { Group (B) } \\
(\mathrm{n}=20)\end{array}$ & $\begin{array}{c}t- \\
\text { value }\end{array}$ & $\begin{array}{c}p \text { - } \\
\text { value }\end{array}$ \\
\hline Pre-treatment & $-0.935 \pm 0.104$ & $-0.970 \pm 0.098$ & 1.096 & 0.280 (NS) \\
Post-treatment & $-0.775 \pm 0.097$ & $-0.885 \pm 0.088$ & 3.773 & 0.001 (S) \\
\hline
\end{tabular}

Data are expressed as mean $\pm \mathrm{SD}$

NS: $p>0.05$ : Not Significant.

$\mathrm{S}: p<0.05$ : Significant

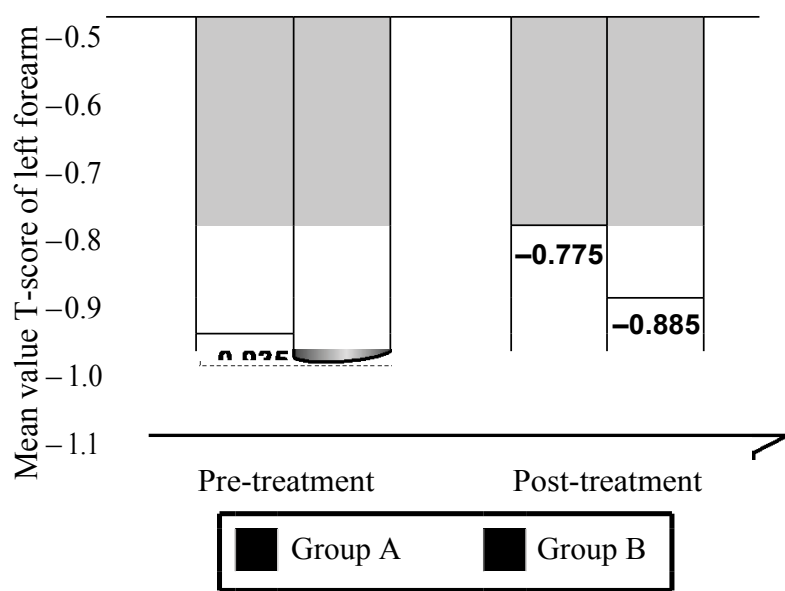

Fig. (9): Comparison between mean values of T score in left fore arm in both groups (A \& B) measured pre-and post-treatment. 


\section{Discussion}

Osteoporosis is characterized by excessively low bone density, bone fragility and increased risk of fracture with relatively minor trauma [16]. Osteoporosis is a major, public, healthy problem, which increases proportionally according to age. It is a skeletal disorder compromising bone strength, and predisposing the subject to an increased risk of fractures in the hip, spine, and other sites [17].

Exercise plays an essential role in the treatment of osteoporosis. Anaerobic and aerobic training have been shown to be effective methods of exercise for improving BMD and reducing bone loss [14].

This study was conducted to determine the effect of aerobic exercises on bone mineral density in lean postmenopausal women.

This study was conducted on forty osteoporotic lean postmenopausal women. They were selected from Physiotherapy Department in Abu El-Matameer General Hospital in Abu El-Matameer City, Behera Governate. Duration of this study was 6 months from January 2017 to July 2017. Their ages were ranged from 49-69 years. Their Body Mass Index (BMI) was less than $25 \mathrm{~kg} / \mathrm{m}^{2}$. Their $\mathrm{T}$-Score was less than -2.5 .

They were divided randomly into two groups equal in number (A and B). Group A (study group) performed aerobic exercise in the form of walking on treadmill, for thirty minutes, three times per week for twelve weeks, starting with warming up exercises and ended by cooling down exercises in addition to their usual daily calcium intake (cal preg tablets $1200 \mathrm{mg} /$ day). Group B (control group) took only their usual daily calcium intake (cal preg tablets $1200 \mathrm{mg}$ /day).

All women in both groups (A and B) were assessed pre and post-treatment through measuring Bone Mineral Density (BMD) of lumbar regain, left femur and forearm by using DEXA.

The results showed that: There was highly statistical significant increase in the mean values of BMD and T-score of lumbar spine, left femur and forearm post-treatment in both groups $\mathrm{A}$ and $B$. There was no statistical significant difference between both groups (A \& B) pre-treatment in the mean values of BMD \& T-score of lumbar spine, left femur and forearm where the $p$-value was $(>0.05)$. While, post-treatment there was a statistical significant difference between both groups (A \& B) in the mean values of BMD \& T-score of lumbar spine, left femur and for arm where, the $p$-value was $(<0.05)$ in favor of group A (more increase).

The results of this study agreed with that of Kelley et al., [18] who suggested that exercise increases femur trochanteric BMD in calciumreplete post-menopausal women.

The results were also, agreed with Varsavsky et al., [19] who found that aerobic physical exercise according to WHO guidelines in the last three months can lead to a decrease in serum Sex Hormone Binding Globulin (SHBG) and increase bone density in the lumbar spine is a significant but not significant increase in hip bone density was observed. Based on these results it can be stated that SHBG serum levels of physical activity reduced and increase bone density also occurs that this increase is meaningful in the lumbar spine but femur may require a longer duration of physical activity may increase bone density.

The results were also, agreed with Hulteen et al., [20] who found that free-living Physical Activity (PA) and exercise are associated with both crosssectional and prospective significant but modest improvement in $\mathrm{BMD}$, at the very least, appear to exert homeostatic influences on BMD during aging. Specifically, research appears to indicate that aerobic exercise may be most efficacious for maintaining and increasing BMD in older women.

The results of this study supported by Bonaiuti et al., [21] who suggested that aerobic exercises improve BMD at the spine and wrist effectively.

The results were also, supported by Evans et al., [22] who found that postmenopausal women who participated in different modes of exercises had statistically significant increases in BMD compared with control groups who did not exercise.

The results of this study also, supported by Nelson et al., [23] who suggested that all prescribed exercise programs, including aerobic exercise, resistance exercises or walking are effective at 1 year or more in slowing loss of bone marrow density. Fast walking is recommended as the best prevention and treatment strategy for osteoporosis in postmenopausal women as it is most similar to activities of daily living and may produce the greatest compliance.

The results were also, supported by Yamazaki et al., [24] who found that treadmill running was effective in prevention of bone loss. Especially, trabecular thickness was kept in treadmill running 
rats. It was suggested that bone loss was inhibited by exercise and this differs by the loading situation.

The results of this study come in consistence with Angin and Erden, [25] who suggested that exercise program has positive influence in increasing BMD and quality of life. For the post-menopausal women with osteoporosis who participated in the program it was possible to stabilize the BMD of lumbar site, and to reduce fracture.

The results also, come in consistence with Lange et al., [26] who found that physical activity has decelerating effect on none loss rate in postmenopausal women.

The results of this study agreed with Chan et al., [27] who found that walking was recommended as suitable activity for increasing bone density. Walking is the easiest and best available form of physical activity, which can be practiced virtually any were, poses only small risks of injury and requires negligible financial demands. The most effective method of prevention of osteoporosis is brisk walking.

The results were also, agreed with Von-Stengel et al., [28] who suggested that low impact loading activity could be effective in reducing bone loss at the hip and spine. Exercise has an important positive effect on the deceleration of decline in BMD.

Exercise induces an anabolic or homeostatic effect on bone via mechanotransduction. Briefly, fluid movement within the extracellular matrix of bone exerts force on osteocytes and bone lining cells. This subsequently triggers the release of nitric oxide and prostaglandin, which lead to division and differentiation of osteoprogenitor cells. Pre-osteoblasts consequently mature to osteoblast cells and affix to the surface of the matrix to begin the production of new bone. Muscular contractions may also induce this extracellular fluid shear stress within the bone matrix, producing deformations in bone. Similarly, gravitational impacts produce deformations via fluid shear stresses and subsequent mechanotransduction. However, these may have limited effects on organism-wide BMD as the skeletal sites most proximal to the engaged muscle groups or sites of gravitational impact during training are likely to experience the greatest increases in BMD [29]

The results disagreed by Tracey et al., [30] who found that moderate forms of exercise such as walking have been disappointing interventions. Based on increasing walking duration and speed have not been successful for improving BMD except at the calcaneus.

The results were also, disagreed by Liang et al., [31] who found that aerobic exercises such as walking are of relatively low intensity, i.e. small mechanical stimuli to muscles, so their effect on bone mass is not significant.

Researchers have shown that training effects were likely to disappear after the training was discontinues and BMD decreased after the completions of the exercise [32].

The results were also, disagreed by Gombos et al., [33] who reported that 8 year after cessation of the 2 year exercise program, the aerobic exercised group had a loss in BMD but the loss in BMD was significantly less in the aerobic exercised group than in the control group. Since these exerciseinduced adaptations are reversible it is important for individuals to remain physically active throughout their entire life span. Postmenopausal women should maintain a lifestyle with ferula exercise to prevent osteoporosis and osteoporotic fractures in later years.

\section{Conclusion:}

On the basis of the data obtained in this study, we can conclude that aerobic exercise is very effective in improving bone mineral density in lean postmenopausal women.

\section{References}

1- INNES K.: Mind-body therapies for menopausal symptoms, a systematic review Maturitas, 66 (2): 135-49, 2010.

2- SAMMEL P.: The Stages of a Woman's Life: Menstruation, Pregnancy, Nursing, Perimenopause, and Menopause., Three Rivers, New York, pp. 56-70, 2008.

3- NIKPOUR S. and HAGHANI H.: The effect of exercise on quality of life in postmenopausal women referred to the Bone densitometry centers of Iran University of Medical Sciences, J. Midlife Health, 5 (4): 176-9, 2014.

4- SAMBROOK P. and COOPER C.: Osteoporosis. Lancet, 367: 2010-8, 2010.

5- KANIS J.: Diagnosis of osteoporosis and assessment of fracture risk. Lancet, 359: 1929-36, 2002.

6- KANIS J., ODEN A., JOHNELL 0., JOHANSSON H., De LAET C. and BROWN J.: The use of clinical risk factors enhances the perfunuauce uf BMD iu the prediction of hip and osteoporotic fractures in men and women. Osteoporos. Int., 18: 1033-46, 2007.

7- COLE R.: Improving clinical decisions for women at risk of osteoporosis: Dual femur bone mineral density testing. J. Am. Osteopath. Assoc., 108 (6): 289-95, 2008.

8- DOUCHI T., YAMAMOTO S., OKI T., MARUTA K. and KUWAHATA: Difference in the effect of adiposity on 
bone density between pre-and postmenopausal women Maturitas, 261: 266-34.

9- KANIS J.: Diagnosis of osteoporosis and assessment of fracture risk. Lancet, 359: 1929-36, 2006.

10- HARRIS S., DALLAL G. and DAWSON-HUGES B.: Influence of body weight on rates of change in bone density of the spine, hip, and radius in postmenopausal women. Calcif. Tissue Int., 50: 19-23, 2007.

11- BLACK D. and ROSEN C.: Clinical practice. Postmenopausal osteoporosis. N. Engl. J. Med., 374 (3): 254-62, 2016.

12- FRENG X. and McDONALD J.: Disorders of bone remodeling Annu. Rev. Pathol., 6: 121-45, 2011.

13- DRAKE M., McCREADY L., HOEY K., ATKINSON E. and KHISLA S.: Effects of suppression of follicle-stemulating hormone secretion hormone on bone resorption markers in postmenopausal women. J. Clinendorinolmetan, 95: 5063-8, 2010 .

14- ROGHANI T., TORKAMAN G., MOVASSEGHE S., HEDAYATI M., GOOSHEH B. and BAYAT N.: Effects of short-term aerobic exercise with and without external loading on bone metabolism and balance in postmenopausal women with osteoporosis. Rheumatol. Int., 33: 2918, 2013.

15- GOMEZ-CABELLO A., ARA I., GONZÁLEZ-AGÜERO A., CASAJÚS J.A. and VICENTE-RODRÍGUEZ G.: Effects of training on bone mass in older adults: A systematic review. Sports Med., 42: 301-25, 2012.

16- AUYEUNG T.W., LEE S.W., LEUNG J., KWOK T. and WOO J.: Age-associated decline ofmuscle mass, grip strength and gait speed: A 4-year longitudinal study of 3018 community dwelling older Chinese. Geriatr. Gerontol. Int., 14 (Suppl 1): 76-84, 2014.

17- LANE N.: Epidemiology, etiology, and diagnosis of osteoporosis. Am. J. Obstet. Gynecol., 194 (2): S3-S11, 2006.

18- KELLEY G.: Exercise and regional bone mineral density in postmenopausal women. Am. J. Phys. Med. Rehabil., 77: 76-87, 2015.

19-VANDER D., GEUSENS P. and DINANT G.: Risk factors for osteoporosis related to their outcome: Fractures. Osteoporos Int., 12: 630-8, 2006.

20- VARSAVSKY M., REYES-GARCÍA R., GARCÍAMARTIN A. and GONZÁLEZ-RAMIREZ A.: Avilés Perez, M. Muñoz-Torres. Osteoporos. Int., 24: 721, 2013.

21- BERGSTROM I., PARINI P., GUSTAFSSON S.A., ANDERSSON G. and BRINCK J.: Physical training increases osteoprotegerin in postmenopausal women. J. Bone Miner. Metab., 30: 202-7, 2012.

22- EVANS E., RACETTE S., VAN PELT R., PETERSON L. and VILLAREAL D.: Effects of soy protein isolate and moderate exercise on bone turnover and bone mineral density in postmenopausal women. Menopause, 14 (3 Pt 1): 481-8, 2007.
23- NELSON M., FISHER E. and DILMANIAN F.: A 1-Y walking program and increased dietary calcium in postmenopausal women on effect on bone. A. J., Clini. Nutr., 53: 1304-11, 2005.

24- YAMAZAKI S., ICHIMURA S., IWAMOTO J., TAKEDA T. and TOYAMA Y.: Effect of walking exercise on bone metabolism in postmenopausal women with osteopenia/ osteoporosis. Journal of Bone and Mineral Metabolism, 22 (5): 500-8, 2004.

25- ANGIN E. and ERDEN Z.: Menopoz sonrasi osteoporoz ve osteopenide grup egzersizlerinin etkinligi [The effect of group exercise on postmenopausal osteoporosis and osteopenia. In Turkish] Acta Orthopaedica et Traumatologica Turcica, Vol. 43, No. 4, pp. 343-50, 2009.

26- LANGE U., TARNER I., TEICHMANN J., STRUNK J., MÜLLER-LADNER U. and UHLEMANN C.: Stellenwert sportlicher betätigung zur prävention und therapie der osteoporose-Eine aktuelle übersicht. The role of exercise in the prevention and rehabilitation of osteoporosis-a current review. In German. Aktuelle Rheumatologie, 32 (1): 21-6, 2007.

27- CHAN B., MARSHALL L., WINTERS K., FAULKNER K., SCHWARTZ A. and ORWOLL E.: Incident fall risk and physical activity and physical performance among older men the osteoporotic fractures in men study. American Journal of Epidemiology, 165 (6): 696-703, 2007.

28- VON STENGEL S., KEMMLER W., ENGELKE K. and KALENDER W.: Effects of whole body vibration on bone mineral density and falls: Results of the randomized controlled ELVIS study with postmenopausal women. Osteoporosis International, 22 (1): 317-25, 2011.

29- WARDEN S.J., HURST J.A., SANDERS M.S., TURNER C.H., BURR D.B. and LI J.: Bone Adaptation to a Mechanical Loading Program Significantly Increases Skeletal Fatigue Resistance. J. Bone Miner. Res., 20: 809-16, 2004.

30- TRACEY E., BEVERLEY S., LESLEY J., FIONA D., ANN M., CRAIG R., ROBIN T., LYNN M. and GISELA C.: Exercise for preventing and treating osteoporosis in postmenopausal women, 6 (2): 6-8, 2011.

31- LIANG M., BRAUN W., BASSIN S., DUTTO D., PONTELLO A., WONG N., SPALDING T. and ARNAUD S. Effect of high-impact aerobics and strength training on BMD in young women aged 20-35 years. International Journal of Sports Medicine, 32 (2): 100-8, 2011.

32- McMILLAN L., ZENGIN A., EBELING P. and SCOTT D.: Prescribing Physical Activity for the Prevention and Treatment of Osteoporosis in Older Adults. Healthcare (Basel), 6; 5 (4). pii: E85, 2017.

33- GOMBOS C.G., BAJSZ V., SIO E., STEINHAUSZ TÓTH V. and SCHMIDT B.: The direct effect of specific training and walking on bone metabolic markers in young adults with peak bone mass. Acta Physiol. Hung., 101: 205-15, 2014. 


\section{تآثير التمرينات الهوائية على كثافة العظام فى السيدات النحيفات بعد إنقطاع الطمث}

آجريت هذه الدراسة لمعرفة تآثّير التمرينات الهوائية على كثافة العظام فى السيدات النحيفات بعد إنقطاع الطمث. شارك في هذه الدئ الدراسة

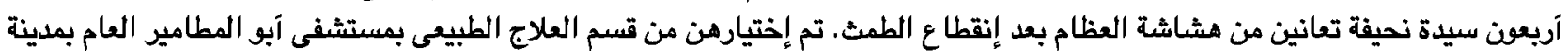

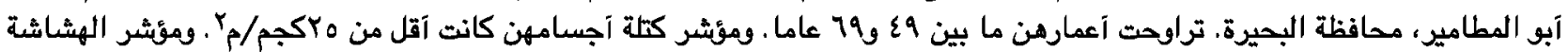

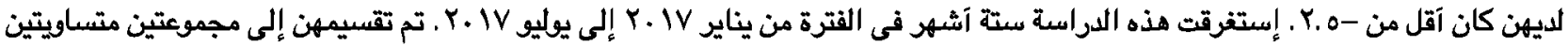

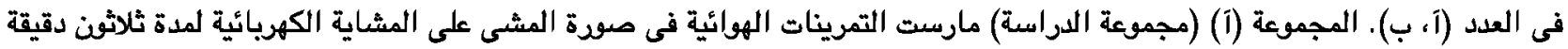

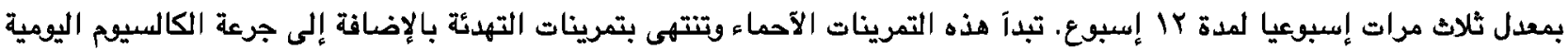

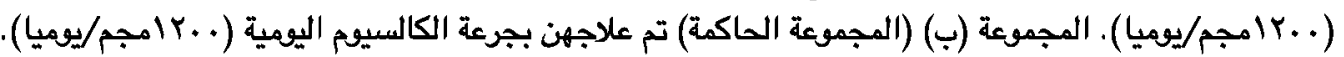

تم تقييم العظام فى المنطقة القطنية، عظم الفذذ اليسرى والساعد لجميع السيدات فى المجموعتين (آ، ب) قبل وبعد العلاج بإستخدام جهاز الآثعة السينية ثنائي الطاقة.

آوضحت النتائج وجود زيادة ذات دلالة إحصائية عالية فى كثافة العظام ومؤشر كثافة العظام فى المنطقة القطنية، عظم الفخذ اليسرىى

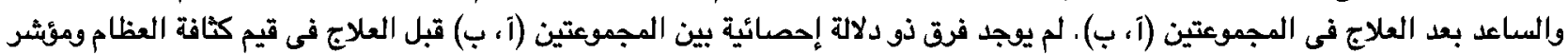

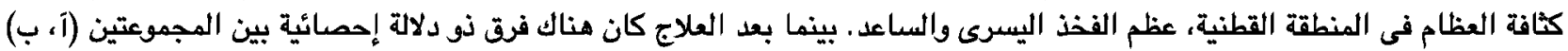
فى قيم كتافة العظام ومؤشركتافة العظام فى المنطقة القطنية، عظم الفخذ اليسرى والساعداء. من هذه التتائج يمكن آن نستخلص آن التمرينات الهوائية فعالة فى تحسين كثافة العظام لدى السيدات النحيفات بعد إنقطاع الطمث. 